\title{
THE HISTORY OF MELANOMA DIAGNOSTICS
}

\author{
Paula Kamińska ${ }^{1}$, Karolina Buszka ${ }^{1}$, Michał Nowicki ${ }^{1}$, Joanna Budna-Tukan ${ }^{1}$
}

\begin{abstract}
This article provides a historical overview of melanoma, involving the knowledge of this neoplasm from antiquity to the present. Selected people who made key descriptions of the disease, its symptoms, and treatment methods were listed. The classification of melanoma, which is used in therapeutic management nowadays, is briefly discussed. Additionally, we describe circulating tumour cells and the selected diagnostic methods associated with their detection and characteristics. The aim of this article is to present a historical outline of melanoma, as well as its classification and the development of laboratory methods of its diagnosis. In addition, we have also provided a comparison of historical and current knowledge of this malignancy.
\end{abstract}

Running title: Melanoma diagnostics - history

Keywords: melanoma, diagnostics, history, classification, circulating tumor cells 


\section{Introduction}

Today's science has considerable knowledge of malignant melanoma. This disease derives from abnormal melanocytes [1] and is characterised with a dynamic course, which in many cases causes low treatability. The American Cancer Society reports that melanoma, despite its rare prevalence compared to other types of cancer, is associated with high mortality rate. Predisposing factors include excessive exposure to UV light, family history, clear skin phototype, and the presence of a large number of birthmarks [2]. The use of photoprotection and prophylactic measures (e.g. regular observation of birthmarks) effectively reduce the risk of developing the disease, and constantly improved diagnostic methods promote its rapid detection and thus more effective treatment.

Today, this malignancy is widely described, although it took about two hundred years to complete the knowledge, during which scientists described the course of the disease among hundreds of patients, analyzed the methods of their treatment, as well as evaluated the effectiveness of the actions taken. This scientific achievement led to further discoveries, not only in the field of the disease itself, but, for example, in the development of a range of laboratory diagnostic methods.

The aim of this article is to present a historical outline of melanoma, as well as its classification and the development of laboratory methods of its diagnosis. In addition, we have also provided a comparison of historical and current knowledge of this malignancy.

\section{Perception of melanoma - from antiquity to modern times; the importance of histology}

Melanoma was most probably a problem that humanity struggled with as early as antiquity. Evidence supporting this thesis was drawn from a study of mummies dating back to the 4 th century BC, during which numerous bone metastases were discovered, together with melanotic changes in skin residues [3]. Skeptical voices, however, indicate that changes to such old remains may be the result of completely different diseases and may even have arisen posthumously, and the lack of complete information on the "patient" does not allow solid conclusions to be made. The fact is that the first discovered ancient mention of melanoma dates back to the 5th century $\mathrm{BC}$ and was noted by Hippocrates, as well as Rufus of Ephesus [3,4]. However, little is known about whether the disease was treated at all.

The beginning of the deepening of knowledge about melanoma dates back to around the 17th-19th century. At that time, the first full descriptions of the disease and the methods of its treatment (mostly surgical) appeared, which made a huge contribution to the development of current medical procedures.
Initially, assessment of the disease was possible only through lesion observation. In addition, there were no criteria to facilitate the correct diagnosis of the malignancy. Descriptions of "fatal black tumours with metastases and black liquid in the body" are already found in "Highmore (1651), Bartholin (1677), Bonet (1679) and Henrici and Nothnagel (1757)" $[4,5]$.

One of the first and leading people in the history of melanoma is John Hunter, who in 1787 performed, for the first-time, a resection of the lesion in a 35-yearold patient. The event caused the surgical excision to enter routine practice, although Hunter believed it was a fungal, rather than cancerous, disease [6].

In the early 19th century, another researcher, Rene Laennec, described melanoma as "melanosis (la melanose)" in 1812 [4,7]. During his studies, he conducted an autopsy, during which he identified characteristic cancerous lesions: dark masses, different from tuberculous lesions commonly observed at that time. After excising and analyzing said tumor, he concluded that, "it contains protein and a specific coloring agent". This agent was most likely melanin produced by melanocytes [8]. In addition, he noted that the occurrence of lesions does not cause an increase in body temperature, which is typical e.g. in tuberculosis [9].

It wasn't just skin melanoma that attracted the interest of 19 th-century scientists. In 1826, Thomas Fawdington described the case of a 30-year-old man suffering from eye melanoma. It was removed, but despite this, the patient experienced skin metastases in the face. They had a black coloration, and their size was compared to a lead projectile. After a while, the patient began to exhibit breathing problems, and the disease spread to further locations. After his death, an autopsy was performed, during which numerous scattered tumors were noted. This description provided detailed information about the nature and rate of metastasis, as well as how important it is to immediately resect the affected organ. In addition, it was noted that the source of the primary disease could be the eyeball, with skin lesions themselves only occurring at a later stage [10].

Robert Carswell, in 1838, first used the term "melanoma" to describe pigmented malignancies [4]. Carswell's work was very important in the history of medicine. In addition to introducing the concept of melanoma, he created an atlas consisting of drawings and watercolor paintings of tissues and organs affected by a range of diseases, e.g. aortic aneurysm caused by syphilis, aortic stenosis, Hodgkin's disease, etc. In addition, he also depicted the brain and spinal cord [11], which contributed to the development of anatomical sciences.

A work by William Norris [12], published in 1857, described eight cases of melanoma. The author called the disease "melanosis" and looked at its causes in the environment in which the patient lived 
- smoky places contaminated with coal dust, typical of industrial districts, and pointed to active and passive smoking as a factor in the disease. In addition, it was already noted that there may be a transmission of the disease to other organs through the vessels, forming metastases. The patients described by the author were ill even at a young age and had a positive family history, which clearly indicated the heredity of the disease. They often showed features known today as a light phototype: light skin (often with freckles), light or red hair, difficulty sunbathing or red tan [2]. At that time, surgical excision was considered to be the primary therapeutic method, but as the described case of a 59-year-old man indicates, the margin of excision was not always correctly calculated resulting in relapse of the disesase [12].

A year later, Oliver Pemberton suggested broad and deep excision of lesion, together with the underlying fascia, and removal of inch lymph nodes as an effective treatment for melanoma [4]. A similar approach was taken by Hogarth Pringle in 1908, who recommended such an excision to cover the site of primary melanoma, regional lymph nodes and a wide strip of skin, subcutaneous fat and fascia between the original lesion and the secondary occupied nodes [13]. Herbert Snow, in his work on melanoma, also advocated the concept of excision lymph nodes before cancer cells spread to the bloodstream. He claimed that this increases the effectiveness of the surgery and promotes patient recovery [14]. Although this procedure has become routine [4], today's science focuses on making resection as effective as possible and stopping the cancer progress, but at the same time not impairing the function of neighboring tissues and organs without a clear necessity. Prophylactic excision of each lesion was questioned in a 1970 work of Alexander Breslow [15]. However, the state of medicine at the time did not allow for precise determination of the stage of the disease, hence the ideas of Pemberton, Pringle and Snow were considered the best possible in given conditions.

The interest of scientists and doctors also focused on lesions observed in children. In 1910, a melanoma-like melanocyte lesion was first described in an eight-month-old boy. However, on the basis of histological characteristics at the time, it was not possible to tell whether the child had melanoma. It was not until 1939 that it was possible to identify the type of lesion found in children and to capture the histological difference between it and the type of occurring in adults. The proposed solution was to excise the lesion in the child to prevent future development of cancer [16].

In 1948, an article by Sophie Spitz, titled "Melanoma of Childhood", appeared in the American Journal of Pathology. This work radically changed the diagnostic criteria and interpretation of some melanocytic changes. Spitz also introduced the term "juve- nilemelanoma" [16]. Today, most of these changes in children are known as Spitz lesions, as they are not malign. They are differentiated on the basis of a characteristic histological picture ("spindle/epithelioid cells at the cutaneous-epidermal border"). Spitz lesions should be surgically removed, preferably before puberty [17].

Crucial to the development of prevention and new treatments of melanoma was the discovery made by in 1956 by Henry Lancaster, linking solar exposure and an increased risk of melanoma development. His research focused on Caucasians in the Australian population, with the discovery of this correlation significantly contributing to the attempts to learn the genetics of melanoma [18]. Today it is known that UVA and UVB radiation contributes to damage to the DNA of cells, proteins and lipids, leading to gene mutations and genomic instability. These mechanisms are further promoted by e.g. age and genetic predisposition, as well as impaired innate defenses (e.g. DNA repair mechanisms) [19].

The history of melanoma is interconnected with the history of histology and histopathology. Without these elements, the development of histopathological diagnosis could not have occurred. An event of great importance for the development of these sciences was the improvement of the microscope by J.J. Lister [20]. The discovery of staining used to visualize desired histological structures was equally important. The most popular staining in histology, hematoxylin and eosin, was first described between 1875 and 1878 [21]. For histopathology, the key moment was the appearance of Johannes Müller's book in 1838 [22]. Immunohistochemical methods based on cancer markers were popularized in the 1980s and are constantly being improved (more below) [21].

\section{Classification of melanoma}

Detailed descriptions of melanoma in the following years contributed to new discoveries and better understanding of the disease. Melanoma classifications have been created to make it easier to assess clinical cases and implement appropriate treatment.

In 1968, Bodenham et al. presented the clinical classification of melanoma, characterizing "good and bad" tumors. "Good" tumors are considered to be limited to one location, rarely metastatic, slowly growing, etc. In turn, "bad" tumors metastasize at an early stage, sometimes do not have pigment (amelanotic melanoma), are difficult to diagnose, ulcerative and diffused (lack of lesion consistency) [23].

Initially, the clinician examining the lesion had at his disposal only the bare eye and professional experience, determining if the lesion should be removed. However, in the 1980s, another tool was used for diagnostics - a dermatoscope, the concept of which was already known in the 17th century [24]. It is a tool that enlarges and reveals selected 
skin structures and their detail, allowing for their thorough examination [25].

Conventional therapeutic procedure of melanoma is based on surgical excision of the lesion, further subjecting it to histopathological analysis. All "disturbing" lesions e.g. asymmetrical, with current ulcers, etc. are removed. The presence of abnormal cells in the histopathological picture [26] predisposes to extension of the boundaries of the original excision [27]. Modern histopathological assessment includes examinations of Breslow thickness and mitosis index [28].

Wallace Clark first suggested that classification should be based on histological characteristics, which at the time was a revolutionary solution. He distinguished histological variants of melanoma [6], which are currently (with modifications) indicated by the World Health Organisation in the following form: Superficial Spreading Melanoma (SSM), Lentigo Maligna Melanoma (LMM), Nodular Melanoma (NM) and Acrolentiginous Melanoma (ALM) [29,30].

In 1966, Clark proposed a melanoma evaluation system based on the depth of cell invasion. The deeper the melanoma cells are present, the greater the risk of metastasis:

- $\quad$ Stage 1: melanoma cells are limited to the epidermis (melanoma in situ),

- $\quad$ Stage 2: invasion of single cells or very small melanoma nests into papillary skin,

- $\quad$ Stage 3: melanoma cells 'fill and dilate' the papillary dermis,

- $\quad$ Stage 4: invasion of reticular dermis,

- $\quad$ Stage 5: invasion of subcutaneous adipose tissue [6].

Although Clark's classification allows you to correctly determine the risks and malignancy of the disease [6], Breslow et al., in 1970 [15] presented a work that highlighted the thickness and size of melanoma in the prognosis. The method turned out to be more accurate, which was confirmed in the 1991 work of Colloby et al. It was acknowledged that measuring the thickness of the lesion is the best method for assessing the cancer and its prognosis. It was also pointed out that Breslow's thickness is a more repeatable measurement than Clark's classification [31].

\section{Circulating cancer cells and examples of laboratory melanoma diagnostic methods}

Melanoma is an aggressive and rapidly progressing, making immediate diagnosis and treatment particularly important [1].

Immunohistochemical methods are useful, distinguishing melanoma from benign lesions and other types of cancer and allowing to determine patient prognosis [32]. Tumor markers are used for such analyses, i.e. a variety of antigens (proteins) on the basis of which the presence (and identity) of cancer cells can be determined [33].
In recent years, Circulating Tumour Cells (CTCs) have attracted a significant interest of the scientific community. CTCs are derived from the primary tumour. By moving through blood and/or lymphatic vessels, they lead to the formation of tumor metastases. This is accompanied by various processes, e.g. change of cell phenotype, destruction of vascular walls, that facilitate the formation of a secondary tumor [34]. In addition, cancer cells, moving through the circulatory system, release their genetic material and exosomes, which can also be used in cancer diagnosis, as a valuable source of information about the disease progression $[35,36]$. As a consequence, it resulted in the development of methods that would make it possible to implement CTC for modern cancer diagnosis, including melanoma. Melanoma CTCs are known in the literature as Circulating Melanoma Cells (CMC) $[37,38]$.

The first reports of circulating tumour cells were presented in 1869 [39] by Thomas Ashworth. He noted that blood sample examinations show cells identical to those derived from the tumor itself, which questioned the genesis of tumor formation at the time, and that abnormal cells can travel long distances in the circulatory system [40]. In turn, (cellfree DNA, cfDNA) was first described almost a hundred years later, in 1948, by Mandel and Metais [41].

In 1960, R.F. Alexander and A.I. Spriggs pointed out a small amount of works describing the isolation of cancer cells from the blood, while tumor metastasis via bloodstream was already a widely known concept at the time. The diagnostic problem that led to this occurrence is a small amount of CTC relative to blood cells (for melanoma, on average, 2 circulating tumor cells correspond to 5 billion blood cells [37]), which hindered the effectiveness of analysis. The introduction of effective methods of separating red and white blood cells has contributed to new attempts to identify circulating tumor cells, which yielded satisfactory results and further development of the methods [42]. Although the problem of low CTC concentration in the sample remained a challenge for scientists for a long time, it was solved in the modern day through the introduction of an 'enrichment stage' (used e.g. in the EPISPOT method), increasing the density of cells in the sample [34].

In the EPISPOT method (Epithelial ImmunoSPOT, modification of ELISPOT-Enzyme - Linked Immuno$S P O T$ ), proteins secreted by live circulating tumour cells, i.e. those that have the ability to form metastases are detected in the sample [43], due to their significant predictive importance. The first EPISPOT articles available in PubMed date back to 2009 (according to PubMed records; ELISPOT data was first compiled in 1983) [44,45]. Furthermore, in the case of melanoma, the $\mathrm{S} 100$ family of proteins is also indicated as a specific marker (the S100-EPISPOT method) [38]. Patients with melanoma have 
increased expression of proteins S100A1, A13 and B. Their presence and quantity allow to determine the progression of the disease and monitor the response to the treatment used [46].

CellSearch ${ }^{\circledR}$ is yet another relatively new method. The first publication in Pubmed records mentioning this topic, „Tumour cells circulate in the peripheral blood of all major carcinomas but not in healthy subjects or patients with nonmalignant diseases", published in 2004, describes the accuracy, precision and linearity of CellSearch $\AA$, as well as the assessment of CTC per $7.5 \mathrm{ml}$ of blood in healthy subjects, patients with non-malignant diseases and patients with various metastatic cancers. The CellSearch ${ }^{\circledR}$ system can be standardized in many laboratories and can used to determine the clinical utility of CTCs. CTCs are extremely rare in healthy individuals and patients with nonmalignant diseases, but are found in various metastatic cancers with a wide range of frequency [47]. The system has also received FDA approval (Food and Drug Administration) as an effective method in the diagnosis of prostate, breast and lung cancer. Immunomagnetically captured from the blood sample and fluorescently decomposed cells expressing selected markers are collected, while excluding leukocytes, identified by CD45 expression, from the analysis. Melanoma cells can be identified by MCAM/CD146 antigen expression [48].

Furthermore, DNA sequencing provides the ability to detect genetic changes specific to many types of cancer, including melanoma. These abnormalities can be detected using e.g. polymerase chain reaction (PCR) methods. The polymerase chain reaction was discovered in 1985 by Kary B. Mullis during his work for Cetus Corporation. He received the Noble Prize in 1993 for his discovery [49].

PCR can be a stand-alone CTC detection method or can be combined with other techniques, with or without real time result analysis [50]. In addition, it has received a number of modifications, such as $R e$ verse-Transcription PCR (RT-PCR) [51,52] or RT-qPCR Reverse transcription-quantitative $P C R$ ), which are used to analyze the mRNA of e.g. cancer cells [53].

\section{Conclusions}

Little is known about the ancient history of melanoma. The findings in this area are challenging due to the lack of solid information about the patients, their environment and way of life. For the benefit of modern man, the 17th-21st century studies provided most of the information on the characteristics of melanoma, which served to improve today's diagnostic methods and treatments. Laboratory methods with increasing sensitivity, which allow to detect melanoma at a very early stage, give increasing hope for full patient recovery. In turn, circulating cancer cells and related diagnostic methods can help to improve cancer diagnosis, not only skin melanoma, but also other malignancies.
The history of melanoma is much more complicated - however, it is difficult to present all the characters and historical events with the appropriate commentary in one article. It is important to appreciate the achievements of scientists from the past, as medicine and diagnostics are still developing, and the following years will certainly show that not everything has been discovered in this regard.

\section{Ethical approval}

The conducted research is not related to either human or animal use.

\section{Acknowledgements}

This research was supported by the grant no. 502-14-2510010045013 from Poznan University of Medical Sciences.

\section{Corresponding author}

Joanna Budna-Tukan, Department of Histology and Embryology, Poznań University of Medical Sciences, Święcickiego 6 St., 61701 Poznań, Poland, tel. +48 618546428, e-mail: jbudna@ump. edu.pl.

\section{Conflict of interests statement}

The authors declare they have no conflict of interest.

\section{References}

1. Ali Z, Yousaf N, Larkin J. Melanoma epidemiology, biology and prognosis. EJC Suppl. 2013;11(2):81-91; DOI:10.1016/j.ejcsup.2013.07.012.

2. Rastrelli M, Tropea S, Rossi CR, Alaibac M. Melanoma: epidemiology, risk factors, pathogenesis, diagnosis and classification. In Vivo. 2014;28(6):1005-11.

3. Morton DL, Essner R, Kirkwood JM, Wollman RC. History of Melanoma. Holland-Frei Cancer Medicine. 6th edition. Hamilton (ON): BC Decker; 2003

4. Urteaga 0, Pack GT. On the antiquity of melanoma. Cancer 1966;19(5):607-10; DOI:10.1002/1097-0142(196605)19:5<607::aid -cncr2820190502>3.0.co;2-8.

5. Rebecca VW, Sondak VK, Smalley KS. A brief history of melanoma: from mummies to mutations. Melanoma Res. 2013;22(2):114-22; DOI:10.1097/CMR.0b013e328351fa4d.

6. Davis LE, Shalin SC, Tackett AJ. Current state of melanoma diagnosis and treatment. Cancer Biol Ther. 2019;20(11):1366-79; DOI:10.1080/1538 4047.2019.1640032.

7. McLeod GR, Davis NC. Historical overview of melanoma. Clinics in Dermatology. 1992; 10(1):5-7; DOI:10.1016/0738-081X(92)90051-Y.

8. Łopusiewicz Ł, Lisiecki S. „Czarne złoto” - melaniny w życiu człowieka. Kosmos. Problemy nauk biologicznych. 2016;65(4):621-9.

9. Lane-Brown M, Roxanas MG. Laennec's melanosis: The first published description of metastatic melanoma. The Australasian Journal of Dermatology. 2017;58(3):234-5; DOI:10.1111/ajd.12492.

10. Mr. Fawdington on Melanosis. Med Chir Rev. 1826;5(10):335-42.

11. https://hekint.org/2020/09/28/sir-robert-carswell-illustrious-medical-illustrator/ (access: 22.11.20).

12. Norris W. Eight cases of melanosis: with pathological and therapeutical remarks on that disease". London: Longman.1857;3-13

13. Pringle J. A Method of Operation in Cases of Melanotic Tumours of the Skin Edinburgh Medical Journal. 1908;23(6):496-99.

14. Neuhaus SJ, Clark MA, Thomas JM. Dr. Herbert Lumley Snow, MD, MRCS (1847-1930): The Original Champion of Elective Lymph Node Dissection in Melanoma. Ann Surg Oncol. 2004;11:875-878; DOI:10.1245/ ASO.2004.02.031.

15. Breslow A. Thickness, cross-sectional areas and depth of invasion in the prognosis of cutaneous melanoma. Ann Surg. 1970;172(5):902-8; DOI:10.1097/00000658-197011000-00017.

16. Manchi M, Canzonieri V. Atypical melanocytic lesions: a historical overview. Pol J Pathol. 2019;70(1):26-32; DOI:10.5114/pjp.2019.84459.

17. Jabłońska S, Majewski S. Choroby skóry i choroby przenoszone drogą płciowa. 2010; Wydawnictwo Lekarskie PZWL:377-8.

18. Gorantla VC, Kirkwood JM. State of melanoma: an historic overview of a field in transition. Hematol Oncol Clin North Am. 2014;28(3):415-35; DOI:10.1016/j.hoc.2014.02.010.

19. Emri G, Paragh G, Tósaki Á, Janka E, Kollár S, Hegedűs C, Gellén E, Horkay I, Koncz G, Remenyik É. Ultraviolet radiation-mediated devel- 
opment of cutaneous melanoma: An update. J Photochem Photobiol B. 2018;185:169-75; DOI:10.1016/j.jphotobiol.2018.06.005.

20. https://blog.labtag.com/a-brief-history-of-histology/

(access: 23.11.2020)

21. Musumeci G. Past, present and future: overview on histology and histopathology. J Histol Histopathol. 2014;1:5; DOI:10.7243/2055-091X-1-5.

22. Haggard HW, Smith GM. Johannes Müller and the Modern Conception of Cancer. Yale J Biol Med. 1938;10(5):419.b1-436.

23. Gong HZ, Zheng HY, Li J. Amelanotic melanoma. Melanoma Res. 2019;29(3):221-30; DOI:10.1097/CMR.0000000000000571.

24. Rao BK, Ahn CS. Dermatoscopy for melanoma and pigmented lesions. Dermatol Clin. 2012; 30(3):413-34; DOI:10.1016/j.det.2012.04.005.

25. Micali G, Lacarrubba F. Dermatoscopy: Instrumental Update. Dermatol Clin. 2018;36(4):345-8; DOI:10.1016/j.det.2018.05.001.

26. Filosa A, Filosa G. Melanoma Diagnosis: The Importance of Histopathological Report. Dermatopathology (Basel). 2018;5(1):41-3; DOI:10.1159/000486670.

27. Mishra H, Mishra PK, Ekielski A, Jaggi M, Iqbal Z, Talegaonkar S. Melanoma treatment: from conventional to nanotechnology. J Cancer Res Clin Oncol. 2018;144(12):2283-2302; DOI:10.1007/s00432-018-2726-1.

28. Zuluaga-Sepúlveda MA, Arellano-Mendoza I, Ocampo-Candiani J. Actualización en el tratamiento quirúrgico del melanoma cutáneo primario y metastásico. Cir Cir. 2016;84(1):77-84; DOI:10.1016/j. circir.2015.06.020.

29. Broekaert SM, Roy R, Okamoto I, van den Oord J, Bauer J, Garbe C, Barnhill RL, Busam KJ, Cochran AJ, Cook MG, Elder DE, McCarthy SW, Mihm MC, Schadendorf D, Scolyer RA, Spatz A, Bastian BC. Genetic and morphologic features for melanoma classification. Pigment Cell Melanoma Res. 2010;23(6):763-70; DOI:10.1111/j.1755-148X.2010.00778.x.

30. Leiter U, Eigentler T, Garbe C. Epidemiology of skin cancer. Adv Exp Med Biol. 2014;810:120-40; DOI:10.1007/978-1-4939-0437-2_7.

31. Colloby PS, West KP, Fletcher A. Observer variation in the measurement of Breslow depth and Clark's level in thin cutaneous malignant melanoma. J Pathol. 1991;163(3):245-50; DOI:10.1002/path.1711630310.

32. Ohsie SJ, Sarantopoulos GP, Cochran AJ, Binder SW. Immunohistochemical characteristics of melanoma. J Cutan Pathol. 2008; 35(5):433-44 DOI:10.1111/j.1600-0560.2007.00891.x.

33. Pitcovski J, Shahar E, Aizenshtein E, Gorodetsky R. Melanoma antigens and related immunological markers. Crit Rev Oncol Hematol. 2017;115:36-49; DOI:10.1016/j.critrevonc.2017.05.001.

34. Kamińska P, Buszka K, Budna-Tukan J. Wybrane metody izolacji i detekcji krążących komórek nowotworowych w różnych typach nowotworów. Post Biol Komórki. 2020;47(2):141-60.

35. Lin J, Li J, Huang B, Liu J, Chen X, Chen XM, Xu YM, Huang LF, Wang XZ. Exosomes: novel biomarkers for clinical diagnosis. Scientific World Journal. 2015;2015:657086; DOI:10.1155/2015/657086

36. Phallen J, Sausen M, Adleff V, Leal A, Hruban C, White J, Anagnostou V, Fiksel J, Cristiano S, Papp E, Speir S, Reinert T, Orntoft MW, Woodward BD, Murphy D, Parpart-Li S, Riley D, Nesselbush M, Sengamalay N, Georgiadis A, Li QK, Madsen MR, Mortensen FV, Huiskens J, Punt C, van Grieken N, Fijneman R, Meijer G, Husain H, Scharpf RB, Diaz LA Jr, Jones S, Angiuoli S, Ørntoft T, Nielsen HJ, Andersen CL, Velculescu VE. Direct detection of early-stage cancers using circulating tumour DNA. Sci Transl Med. 2017;9(403):eaan2415; DOI:10.1126/scitranslmed.aan2415.

37. Rapanotti MC, Campione E, Spallone G, Orlandi A, Bernardini S, Bianchi L. Minimal residual disease in melanoma: circulating melanoma cells and predictive role of MCAM/MUC18/MelCAM/CD146. Cell Death Discov. 2017;3:17005; DOI:10.1038/cddiscovery.2017.5.

38. Cayrefourcq L, De Roeck A, Garcia C, Stoebner PE, Fichel F, Garima F, Perriard F, Daures JP, Meunier L, Alix-Panabières C. S100-EPISPOT: A New Tool to Detect Viable Circulating Melanoma Cells. Cells. 2019;8(7):755; DOI:10.3390/cells8070755.

39. Paoletti C, Hayes DF. Circulating Tumour Cells. Adv Exp Med Biol. 2016;882:235-58; DOI:10.1007/978-3-319-22909-6_10.

40. Nieva JJ, Kuhn P. Fluid biopsy for solid tumours: a patient's companion for lifelong characterization of their disease. Future Oncol. 2012;8(8) 989-98; DOI:10.2217/fon.12.91.

41. Mandel P, Metais P. Les acides nucléiques du plasma sanguin chez l'homme [Nuclear Acids In Human Blood Plasma]. C R Seances Soc Biol Fil. 1948;142(3-4):241-3.

42. Alexander RF, Spriggs AI. The differential diagnosis of tumour cells in circulating blood. J Clin Pathol. 1960;13(5):414-24; DOI:10.1136/ jcp.13.5.414

43. Budna J, Świerczewska M, Jankowiak A, Zabel M. Detekcja krążacych komórek nowotworowych przy zastosowaniu techniki EpiSPOT. Post Bio Komórki. 2015;42(3):401-16.

44. Czerkinsky CC, Nilsson LA, Nygren H, Ouchterlony O, Tarkowski A. A solid-phase enzyme-linked immunospot (ELISPOT) assay for enumeration of specific antibody-secreting cells. J Immunol Methods. 1983;65(12):109-21; DOI:10.1016/0022-1759(83)90308-3.

45. Czerkinsky CC, Svennerholm AM. Ganglioside GM1 enzyme-linked immunospot assay for simple identification of heat-labile enterotoxin-producing Escherichia coli. J Clin Microbiol. 1983;17(6):965-69; DOI:10.1128/jcm.17.6.965-969.1983.

46. Xiong TF, Pan FQ, Li D. Expression and clinical significance of S100 fam ily genes in patients with melanoma. Melanoma Res. 2019;29(1):23-9; DOI:10.1097/CMR.0000000000000512.

47. Allard WJ, Matera J, Miller MC, Repollet M, Connelly MC, Rao C, Tibbe AG, Uhr JW, Terstappen LW. Tumour cells circulate in the peripheral blood of all major carcinomas but not in healthy subjects or patients with nonmalignant diseases. Clin Cancer Res. 2004;10(20): 6897-6904; DOI:10.1158/1078-0432.CCR-04-0378.

48. www.cellsearchruo.com/ruo-products/kits (dostęp: 18.11.2020).

49. Garcia JG, Ma SF. Polymerase chain reaction: a landmark in the history of gene technology. Crit Care Med. 2005;33(12 Suppl):429-32; DOI:10.1097/01.ccm.0000186782.93865.00.

50. Green MR, Sambrook J. Analysis and Normalization of Real-Time Polymerase Chain Reaction (PCR) Experimental Data. Cold Spring Harb Protoc. 2018;2018(10); DOI:10.1101/pdb.top095000.

51. Bachman J. Reverse-transcription PCR (RT-PCR). Methods Enzymol 2013;530:67-74; DOI:10.1016/B978-0-12-420037-1.00002-6.

52. Hinz S, Hendricks A, Wittig A, Schafmayer C, Tepel J, Kalthoff H, Becker T, Röder C. Detection of circulating tumour cells with CK20 RT-PCR is an independent negative prognostic marker in colon cancer patients - a prospective study. BMC Cancer. 2017;17(1):53; DOI:10.1186/ s12885-016-3035-1.

53. Ho-Pun-Cheung A, Bascoul-Mollevi C, Assenat E, Boissière-Michot F, Bibeau F, Cellier D, Ychou M, Lopez-Crapez E. Reverse transcription-quantitative polymerase chain reaction: description of a RIN-based algorithm for accurate data normalization. BMC Mol Biol. 2009; 10:31 DOI:10.1186/1471-2199-10-31. 